\title{
THE EFFECT OF PURSED LIPS BREATHING IN INCREASING OXYGEN SATURATION IN PATIENTS WITH CHRONIC OBSTRUCTIVE PULMONARY DISEASE IN INTERNAL WARD 2 OF THE GENERAL HOSPITAL OF DR. R. SOEDARSONO PASURUAN
}

\author{
Budiono*, Mustayah, Aindrianingsih
}

Department of Nursing, Polytechnic of Health Malang, Ministry of Health Republic of Indonesia

Accepted: 5 September 2017

*Correspondence:

Budiono

Department of Nursing, Polytechnic of Health Malang

Ministry of Health Republic of Indonesia | E-mail: budisumodiwiryo@gmail.com

Copyright: (C) the author(s), YCAB publisher and Public Health of Indonesia. This is an open-access article distributed under the terms of the Creative Commons Attribution Non-Commercial License, which permits unrestricted non-commercial use, distribution, and reproduction in any medium, provided the original work is properly cited.

Background: Chronic obstructive pulmonary disease is a leading cause of death and disability. Thus, the effort to reduce the symptoms, such as dyspnea is necessity. Pursed lip breathing is assumed increasing oxygen saturation.

Objective: This study aims to determine the effect of pursed lips breathing in increasing oxygen saturation in patients with COPD in internal ward 2 of the General Hospital of Dr. R. Soedarsono Pasuruan on May 16 - June 30, 2017.

Methods: This was a pre-experimental design with pre-posttest design. There were 24 patients with COPD selected using simple random sampling technique. Pulse oximetry (oximeter pulse fingertip) was used to measure oxygen saturation. Data were analyzed using Wilcoxon Sign Rank Test.

Results: Findings showed p-value $0.000(<0.05)$, which indicated that there was a statistically significant difference in oxygen saturation before and after pursed lips breathing.

Conclusion: There was a significant effect of pursed lips breathing on oxygen saturation in patients with COPD in the internal ward 2 of the general hospital of Dr. R. Soedarsono Pasuruan. Thus, pursed lips breathing could be applied as a nursing intervention in patients with COPD.
}

Key words: Pursed lips breathing, COPD, oxygen saturation

\section{BACKGROUND}

Chronic Obstructive Pulmonary Disease (COPD) is an irreversible condition in which airway constriction occurs, increased airflow obstruction and loss of lung elastic recoil. The condition causes air trapped and disturbed gas exchange resulting in the syndrome of dyspnea, cough, sputum production increases and wheezing. At a later stage, COPD results in impaired activity tolerance, fatigue, loss of appetite, weight loss and disruption of sleep cycles. ${ }^{1}$

Shortness of breath or dyspnea is a common symptom in people with COPD. The cause of shortness of breath is not only 
due to obstruction in the bronchus or bronchospasm alone, but also due to the presence of hyperinflation. This tightness complaint can be overcome by maintaining adequate ventilation and gas exchange by changing the lying position, ambulation, deep breathing exercises and effective cough to remove mucus. ${ }^{2}$

One of the deep breathing exercises that can be done to reduce dyspnea is by pursed lips breathing (PLB) technique. Pursed Lips Breathing is a breathing exercise that consists of two mechanisms, namely strong and deep inspiration, and active and long expiration. PLB helps the client to control the breath. Pursed lips provide resistance to the air flowing out of the lungs, thereby prolonging the exhalation and preventing airway collapse by maintaining positive pressure on the airway, $\mathrm{CO} 2$ in the lung can be removed and $\mathrm{O} 2$ fills more alveoli. High differences in the $\mathrm{O} 2$ pressure gradient increase gas exchange, in alveoli to pulmonary capillaries. $^{3}$

Pursed Lips Breathing causes the inspiratory muscles to work more optimally so that the burden on the inspiratory muscles is reduced. Research showed that the pattern of PLB significantly increased tidal volume (TV) and lowered respiration rate than natural breathing. ${ }^{4}$ Increasing the amount of oxygen that moves to the pulmonary capillaries increases the amount of oxygen bound by $\mathrm{Hb}$ and can bind $\mathrm{SaO} 2$. Oxygen saturation $(\mathrm{SaO} 2)$ is the ratio of oxygenated hemoglobin ( $\mathrm{HbO} 2)$ level to hemoglobin in the blood (total $\mathrm{HbO} 2$ and deoxygenated hemoglobin), thus $\mathrm{SaO} 2$ increases. Sherwood (2001) suggests that increasing $\mathrm{PaO} 2$ increases $\mathrm{Hb}$ affinity to oxygen, and a decrease in the amount of $\mathrm{CO} 2$ will also increase the affinity of $\mathrm{Hb}$ to oxygen and vice versa. ${ }^{4}$

According to the World Health Organization (WHO), there are 600 million people suffering from COPD in the world, with 65 million people suffering from moderate to severe COPD. This disease is the leading cause of fifth death in the world. It is estimated that more than 3 million people died of COPD in 2005, which is equivalent to $5 \%$ of all deaths globally. ${ }^{5}$ In Indonesia, the incidence of COPD was ranked fifth of eleven noncommunicable diseases and the prevalence of COPD averaged $3.7 \%{ }^{6}$ The results of the non-infectious disease survey by the Directorate General of PPM \& PL at 5 provincial hospitals in Indonesia (West Java, Central Java, East Java, Lampung and South Sumatra) in 2004 showed that COPD was ranked first among the contributors $(35 \%)$, followed by bronchial asthma (33\%), lung cancer $(30 \%)$ and others $(2 \%)^{7}$

The results of preliminary study at the General Hospital of Dr. R. Soedarsono Pasuruan on November 1, 2016 revealed that the intervention conducted in patients with COPD were by giving oxygen and semi fowler position. There was no pursed lip breathing technique. Thus, regarding the phenomena and interventions provided. This study aimed to examine the effect of Pursed Lips Breathing in increasing oxygen saturation in patients with COPD.

\section{METHODS}

\section{Design}

This was a pre-experimental design with pre-posttest design.

\section{Population and Sample}

The study population was 98 people suffering from COPD treated in Internal Room 2 of the General Hospital of Dr. R. Soedarsono Pasuruan. The sample was 24 patients with COPD selected using simple random sampling technique that met the specified inclusion and exclusion criteria from 16 May to 30 June 2017. 


\section{Intervention}

The researcher taught the respondents the pursed lips breathing exercise. After the respondents did the intervention correctly based on the standard of procedure adopted from Smeltzer \& Bare (2007), ${ }^{2}$ then the oxygen saturation was measured as pretest data. The respondents were given pursed lips breathing intervention approximately 15 minutes and a break of 2 minutes. Intervention was given 3 times a day (morning, afternoon and evening) for 4 days. Posttest was implemented after 4 days intervention. While the measurement of oxygen saturation based on standard of procedure adopted from Potter \& Perry. ${ }^{8}$

Pursed lip breathing is a breathing technique designed to make your breaths more effective by making them slower and more intentional. The technique of pursed lips breathing as follows: 1) Sit with back straight or lie down. Relaxing shoulders as much as possible; 2) Inhaling through nose for two seconds and feeling the air move into abdomen. Trying to fill abdomen with air instead of just lungs; 3) Purse lips like blowing on hot food and then breathe out slowly, taking twice as long to exhale as taking to breathe in; 4) Then repeat. Over time, increase the inhale and exhale counts from 2 seconds to 4 seconds, and so on. ${ }^{9}$

\section{Research Instruments}

To measure $\mathrm{O} 2$ saturation, pulse oximetry (oximeter pulse fingertip) was used.

\section{Research Ethics}

Ethical research in this study was obtained from the Ethics Commission of Poltekkes Kemenkes Malang. The study permission was also obtained from the General Hospital of Dr. R. Soedarsono Pasuruan. Informed consent was performed to each respondent.

\section{Data analysis}

Univariate analysis was performed in the form of frequency distribution. The statistical test in this study used Wilcoxon sign rank test to know the difference of oxygen saturation before and after intervention in COPD patients. The data normality test used Shapiro-Wilk analysis to know the normality of data.

\section{RESULTS}

Characteristics of the respondents

Table 1 shows that $71 \%$ of respondents were males and $29 \%$ of them were females.

Table 1. Characteristic of respondents based on gender

\begin{tabular}{|c|c|c|}
\hline Gender & f & \% \\
\hline Male & 17 & 71 \\
\hline Female & 7 & 29 \\
\hline Total & 24 & 100 \\
\hline
\end{tabular}

Table 2. Characteristic of respondents based on age

\begin{tabular}{|c|c|c|c|c|c|}
\hline N & Min & Max & Mean & SD & $\begin{array}{c}\text { Confident } \\
\text { Interval }\end{array}$ \\
\hline 24 & 31 & 69 & 57.74 & 9.939 & 49.34 \\
\hline
\end{tabular}

Based on table 2, it is known that the average age of the respondents was 57.74 years old, with the youngest age was 31 years old, and the oldest was 69 years old, with standard deviation of 9.939 and confident interval of 49.34 . 
Table 3. Characteristic of respondents based on educational level

\begin{tabular}{|c|c|c|}
\hline Educational Level & f & \% \\
\hline Elementary School & 7 & 29 \\
\hline Junior High School & 6 & 25 \\
\hline Senior High School & 10 & 42 \\
\hline Bachelor degree & 1 & 4 \\
\hline Total & 24 & 100 \\
\hline
\end{tabular}

Table 3 shows that $42 \%$ of respondents' educational level was senior high school, $25 \%$ was junior high school, and $29 \%$ was elementary school. While Table 4 shows that the majority of the respondents worked in private organizations/companies $(59 \%)$.

Table 4. Characteristic of respondents based on job

\begin{tabular}{|c|c|c|}
\hline Jobs & f & \% \\
\hline Civil servants & 0 & 0 \\
\hline Private & 14 & 59 \\
\hline Entrepreneur & 2 & 8 \\
\hline Farmer/fisherman & 6 & 25 \\
\hline Unemployed & 2 & 8 \\
\hline Total & 24 & 100 \\
\hline
\end{tabular}

\section{Oxygen Saturation in patients with COPD}

Table 5. Oxygen saturation before and after Pursed lips breathing in patients with COPD

\begin{tabular}{|c|c|c|c|c|}
\hline \multirow{2}{*}{$\begin{array}{c}\text { Oxygen } \\
\text { Saturation }\end{array}$} & Pretest & P & Posttest \\
\cline { 2 - 5 } & $\mathbf{f}$ & $\mathbf{\%}$ & 0 & 0 \\
\hline$<95 \%$ & 14 & 58 & 24 & 100 \\
\hline$\geq 95 \%$ & 10 & 42 & 24 & 100 \\
\hline Total & 24 & 100 & & \\
\hline
\end{tabular}

Based on table 5, it can be seen that before doing pursed lips breathing, more than half of respondents $(58 \%)$ had the oxygen saturation value below normal $(<95 \%)$.
While after pursed lips breathing, the oxygen saturation value was in the normal range ( $\geq 95 \%)$ in all respondents.

Hemoglobin and erythrocytes in patients with COPD

Table 6. Hemoglobin and erythrocytes in patients with COPD

\begin{tabular}{|c|c|c|c|c|}
\hline \multirow{2}{*}{ Range } & \multicolumn{2}{|c|}{ Hemoglobin (Hb) } & \multicolumn{2}{c|}{ Erythrocytes } \\
\cline { 2 - 5 } & f & $\mathbf{\%}$ & f & \% \\
\hline Normal & 22 & 91 & 22 & 91 \\
\hline Less & 2 & 9 & 2 & 9 \\
\hline Total & 24 & 100 & 24 & 100 \\
\hline
\end{tabular}

Table 6 shows that the majority of respondents $(91 \%)$ had normal hemoglobin and erythrocytes. While Wilcoxon test as shown in the Table 7 showed $Z$ count -
4.374 with p-value $0.000(<0.05)$, which indicated that there was a statistically significant difference of oxygen saturation before and after intervention. 


\section{Difference of oxygen saturation before and after intervention}

Table 7. Difference of oxygen saturation before and after pursed lips breathing using Wilcoxon test

\begin{tabular}{|c|c|c|c|c|c|c|}
\hline \multirow{2}{*}{ Variable } & Intervention & $\mathbf{n}$ & Mean & SD & Z & p-value \\
\hline \multirow{2}{*}{ Oxygen saturation } & Before & 24 & 94.33 & 0.963 & -4.374 & 0.000 \\
\cline { 2 - 7 } & After & 24 & 98.13 & 1.035 & & \\
\hline
\end{tabular}

\section{DISCUSSION}

The aim of this study was to examine the effect of pursed lip breathing technique on oxygen saturation in patients with COPD. Findings of this study revealed that there were statistically significant differences of oxygen saturation before and after pursed lip breathing in patients with COPD. It could be said that pursed lip breathing is effective in increasing oxygen saturation. This result is in line with the study of Astuti $^{10}$ indicated that the provision of pursed lip breathing has a significant effect on changes in respiratory patterns in patients with emphysema. Khasanah ${ }^{4}$ also stated that pursed lip breathing effectively decreases respiration rates, shortness of breath and improve $\mathrm{SaO} 2$. Similarly, Aini ${ }^{11}$ mentioned that breathing retraining gives an effect in improving lung ventilation function of patient with COPD.

In addition, Widiyani ${ }^{12}$ revealed that pursed lips breathing exercise had a significant influence on the peak of expiratory exposure of patients with chronic bronchitis, and increase the peak flow of expiration in active smokers Ariestanti. $^{13}$

Pursed lip breathing is a breathing exercise to improve the lung mechanics and breathing all at once. The practice of pursed lips breathing by prolonging the exhalation will increase the amount of trapped carbon dioxide and increase the transport of oxygen, so that the medulla oblongata is not stimulated to increase the effort of breathing because there has been a balance of gas homeostasis in the body, and this will stabilize the respiratory pattern to be effective. ${ }^{10}$

Forcible expiration will increase the strength of intra-abdominal muscle contraction compared to passive expiration, so that intra-abdominal pressure also increases, as well as the movement of the diaphragm to make the thoracic cavity smaller. The smaller thoracic cavity causes intra-alveolus pressure increased and exceeds atmospheric air pressure. The condition will cause air to flow out of the lungs into the atmosphere. The forced expiration of breathing pursed lips breathing will also cause airway obstruction to be removed so that respiratory resistance decreases. ${ }^{4}$

Through a strong and deep inspiration mechanism, pursed lips breathing helps increase the intake of $\mathrm{O} 2$ into the alveoli. The high $\mathrm{O} 2$ pressure in the alveolus compared with the $\mathrm{O} 2$ pressure in the pulmonary capillaries, or low $\mathrm{CO} 2$ pressure in the alveolus compared with the high pressure of $\mathrm{CO} 2$ in the pulmonary capillaries, lead to increased gradient pressure of the gases between the two sides. A high degree of $\mathrm{O} 2$ pressure gradient increases the gas exchange, i.e. the diffusion of $\mathrm{O} 2$ from the alveolus to the pulmonary capillaries. The difference of high $\mathrm{CO} 2$ pressure also increases the gas exchange of $\mathrm{CO} 2$ diffusion from the pulmonary capillaries to the alveolus for subsequent expulsion into the atmosphere. ${ }^{4}$ Increasing the amount of oxygen that moves to the pulmonary capillaries increases the amount of oxygen bound by $\mathrm{Hb}$ and can bind the oxygen saturation. $\mathrm{Hb}$ 
is a component of red blood cells, which the increased number of red blood cells will automatically increase $\mathrm{Hb}$ levels.

In this study, the majority of respondents were males $(71 \%)$. This could be because of the smoking habits. According to Susanti, ${ }^{14}$ half of all people who smoke have a chance of damage or airway obstruction, and $10-20 \%$ of them develop significantly into COPD. In addition, Astuti ${ }^{10}$ stated that emphysema in Indonesia increases along with the increasing risk factors such as increasing number of people smoking at young age. In fact, most of respondents in this study aged 31-60 years. However, certain aspects of lung function, such as vital capacity and strong expansion volume, will decline with age. COPD aggravates many physiological changes were associated with aging and results in airway obstruction in bronchitis and loss of elastic pulmonary growth in emphysema. ${ }^{3}$

On the other hand, low level of education is also revealed in this study, which might affect health risk behaviors. Some types of jobs that directly become a risk factor for COPD such as farmers, industrial workers, miners are likely to decrease the quality of life of COPD patients. ${ }^{3}$ Emphysema disease in Indonesia increases with increasing risk factors for emphysema such as increasing number of people who smoke cigarettes at young age, rapid industrial progress and air pollution. ${ }^{10}$ Important indoor pollutants include $\mathrm{SO} 2, \mathrm{NO} 2$ and $\mathrm{CO}$. Exposure to $\mathrm{SO} 2$ can cause bronchospasm, some $\mathrm{SO} 2$ will be retained in the upper airway because it reacts with water contained in the mucosal lining. And the incidence of respiratory infections increases in people exposed to NO2. It is caused by cilia damage, mucous secretion disturbance and alveolar macrophage function as well as disruption of humoral immunity. While exposure to ozone will be able to increase bronchial hyperactivity in asthma clients as well as on healthy clients. ${ }^{3}$ This will lead to decreased lung function. However, by doing pursed lips breathing 3 times a day for 4 days can reduce respiratory work, increase maximum alveolar inflation, and train the respiratory muscles.

This study provides the insight of knowledge regarding the effect of pursed lips breathing on oxygen saturation in patients with COPD. However, confounding variables might influence the results of this study. Experimental study with pretest posttest with control group design is needed for further explanation.

\section{CONCLUSION}

Based on the results of this study, it can be concluded that there was a significant effect of pursed lips breathing on oxygen saturation in patients with COPD in the internal ward 2 of the General Hospital of Dr. R. Soedarsono Pasuruan. Thus, pursed lips breathing could be applied as a nursing intervention in the hospital.

\section{REFERENCES}

1. Brunner LS. Brunner \& Suddarth's textbook of medical-surgical nursing. Vol 1: Lippincott Williams \& Wilkins; 2010.

2. Smeltzer SC, Bare BG, Hinkle JL, Cheever KH, Townsend MC, Gould B. Brunner \& Suddarth's Textbook of Medical Surgical Nursing 12th Edition: Wolters Kluwer: Lippincott Williams and Wilkins; 2008.

3. Rini IS. Hubungan Antara Efikasi Diri Dengan Kualitas Hidup Pasien Penyakit Paru Obstruksif Kronis Dalam Konteks Asuhan Keperawatan di RS Paru Batu dan RSU DR Saiful Anwar Malang Jawa Timur: Ilmu Keperawatan, Fakultas Ilmu 
Keperawatan, Universitas Indonesia; 2011.

4. Khasanah S, Maryoto M. EFEKTIFITAS POSISI CONDONG KE DEPAN DAN PURSED LIPS BREATHING (PLB) TERHADAP PENINGKATAN SATURASI OKSIGEN PASIEN PENYAKIT PARU OBSTRUKTIF KRONIK. Jurnal Kesehatan Alirsyad (JKA). 2017;7(1):25-35.

5. WHO. Chronic obstructive pulmonary disease (COPD). 2017; http://www.who.int/respiratory/copd/e n/. Accessed 19 May, 2017.

6. Kementerian Kesehatan RI. Laporan Hasil Riset Kesehatan Dasar (Riskesdas) 2013. Jakarta: Kementerian Kesehatan RIDinKes Jateng. 2013.

7. Departemen Kesehatan RI. Pedoman Pengendalian Penyakit paru Obstruktif Kronik. Jakarta: Direktorat Jendral Pengendalian penyakit dan Lingkungan, Direktorat Pengendalian Penyakit Tidak Menular. 2008.

8. Potter PA, Perry AG. Buku ajar fundamental keperawatan: konsep, proses, dan praktik. Jakarta: EGC. 2005; 1 .

9. Gotter A. Pursed Lip Breathing. healthline: Newsletter: HealthLine; 2017.

10. Astuti LW. PENGARUH PURSED LIPS BREATHING TERHADAP POLA PERNAPASAN PADA PASIEN DENGAN EMFISEMA DI RUMAH SAKIT PARU DR. ARIO WIRAWAN SALATIGA: Program Studi Ilmu Keperawatan. Sekolah Tinggi Ilmu Kesehatan Ngudi Waluyo Ungaran; 2014.

11. Aini F, Sitorus R, Budiharto B. Pengaruh Breathing Retraining
Terhadap Peningkatan Fungsi Ventilasi Paru Pada Asuhan Keperawatan Pasien PPOK. Jurnal Keperawatan Indonesia. 2008;12(1):29-33

12. Widiyani CTC. PENGARUH PURSED LIPS BREATHING EXERCISE TERHADAP ARUS PUNCAK EKSPIRASI (APE) PADA PASIEN BRONKITIS KRONIS DI POLI SPESIALIS PARU B RUMAH SAKIT PARU KABUPATEN JEMBER: $\quad$ Program Studi Keperawatan, Universitas Jember; 2015.

13. Ariestianti I, Pangkahila JA, Purnawati S. PEMBERIAN DIAPHRAGMATIC BREATHING SAMA BAIK DENGAN PURSED LIP BRETHING DALAM MENINGKATKAN ARUS PUNCAK EKSPIRASI PADA PEROKOK AKTIF ANGGOTA CLUB MOTOR YAMAHA VIXION BALI DI DENPASAR. Majalah Ilmiah Fisioterapi Indonesia.3(1).

14. Susanti PFE. INFLUENCE OF SMOKING ON CHRONIC OBSTRUCTIVE PULMONARY DISEASE (COPD). Majority. 2015;4(05).

Cite this article as: Budiono, Mustayah, Aindrianingsih. The Effect of Pursed Lips Breathing in Increasing Oxygen Saturation in Patients with Chronic Obstructive Pulmonary Disease in Internal Ward 2 of the General Hospital of Dr. R. Soedarsono Pasuruan. Public Health of Indonesia 2017;3(3):117-123 